\title{
Correction to: Identification and molecular characterization of Wolbachia strains in natural populations of Aedes albopictus in China
}

Yaping $\mathrm{Hu}^{1,2,3^{*}}$, Zhiyong $\mathrm{Xi}^{4+}$, Xiaobo Liu' ${ }^{1}$, Jun Wang ${ }^{1}$, Yuhong Guo ${ }^{1}$, Dongsheng Ren ${ }^{1}$, Haixia Wu' Xiaohua Wang ${ }^{5}$, Bin Chen ${ }^{3^{*}}$ and Qiyong Liu ${ }^{1^{*}}$

\section{Correction to: Parasites Vectors (2020) 13:28}

https://doi.org/10.1186/s13071-020-3899-4

Following publication of the original article [1], the corresponding author flagged that the article had published with two errors.

The first error concerns affiliation ' 1 ', which was incomplete; please find the complete reference in this correction.
While the second is that an incorrect version of Fig. 7 had been used.

For reference, please find (the correct version of) Fig. 7 in this article.

The original article can be found online at https://doi.org/10.1186/s1307

$1-020-3899-4$

*Correspondence: huyap9009@163.com; c_bin@hotmail.com;

liuqiyong@icdc.cn

†Yaping Hu and Zhiyong Xi contributed equally to this work

${ }^{1}$ State Key Laboratory of Infectious Disease Prevention and Control,

Collaborative Innovation Center for Diagnosis and Treatment

of Infectious Diseases, WHO Collaborating Centre for Vector Surveillance and Management, National Institute for Communicable Disease Control

and Prevention, Chinese Center for Disease Control and Prevention,

Beijing 102206, People's Republic of China

3 Institute of Entomology and Molecular Biology, College of Life Sciences,

Chongqing Normal University, Chongqing, China

Full list of author information is available at the end of the article

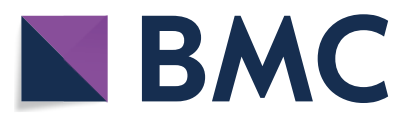

The Author(s) 2020. This article is licensed under a Creative Commons Attribution 4.0 International License, which permits use, sharing, adaptation, distribution and reproduction in any medium or format, as long as you give appropriate credit to the original author(s) and the source, provide a link to the Creative Commons licence, and indicate if changes were made. The images or other third party material in this article are included in the article's Creative Commons licence, unless indicated otherwise in a credit line to the material. If material is not included in the article's Creative Commons licence and your intended use is not permitted by statutory regulation or exceeds the permitted use, you will need to obtain permission directly from the copyright holder. To view a copy of this licence, visit http://creativeco mmons.org/licenses/by/4.0/. The Creative Commons Public Domain Dedication waiver (http://creativecommons.org/publicdomain/ zero/1.0/) applies to the data made available in this article, unless otherwise stated in a credit line to the data. 


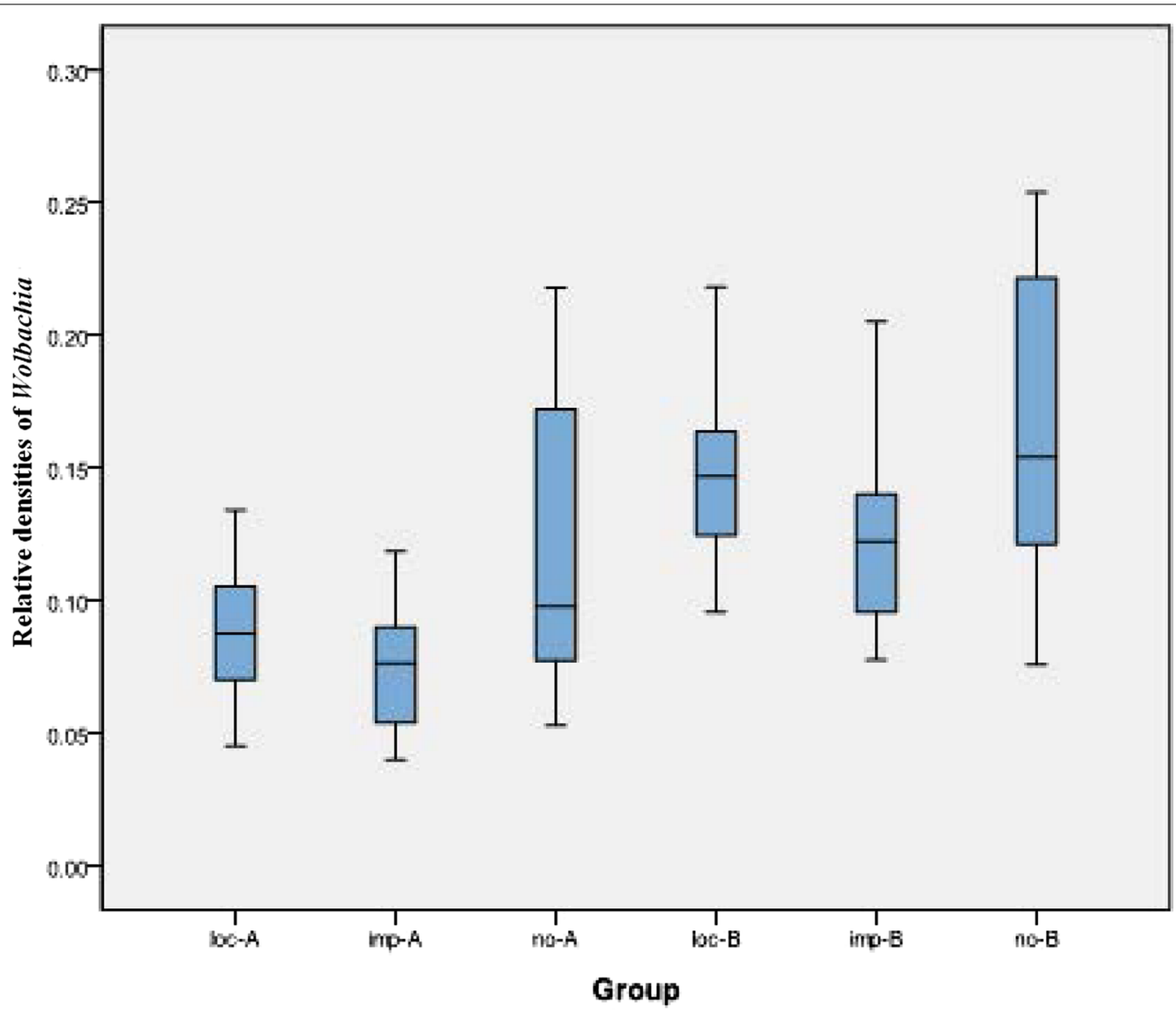

Fig. 7 Relative Wolbachia densities in Ae. albopictus collected in different regions in China. Abbreviations: loc-A, relative densities of WAlbA in the regions with local dengue cases; imp-A, relative densities of $W A$ AlbA in the regions with import dengue cases; no-A, relative densities of $W A$ IbA in the regions without dengue cases; loc-B, relative densities of $w A$ AlbB in the regions with local dengue cases; imp- $B$, relative densities of wAlbB in the regions with import dengue cases; no- $B$, relative densities of $W A l b B$ in the regions without dengue cases

The authors apologize for any inconvenience caused.

\section{Author details}

${ }^{1}$ State Key Laboratory of Infectious Disease Prevention and Control, Collaborative Innovation Center for Diagnosis and Treatment of Infectious Diseases, WHO Collaborating Centre for Vector Surveillance and Management, National Institute for Communicable Disease Control and Prevention, Chinese Center for Disease Control and Prevention, Beijing 102206, People's Republic of China. ${ }^{2}$ Nanjing Institute of Environmental Sciences, Ministry of Ecology and Environment of the People's Republic of China, Nanjing, China. ${ }^{3}$ Institute of Entomology and Molecular Biology, College of Life Sciences, Chongqing Normal University, Chongqing, China. ${ }^{4}$ Key Laboratory of Tropical Disease Control of the Ministry of Education, Sun Yat-sen University-Michigan State University Joint Center of Vector Control for Tropical Diseases, Zhongshan School of Medicine, Sun Yat-sen University, Guangzhou, China. ${ }^{5}$ Haikou Center for Disease Control and Prevention, Haikou, China.

Published online: 12 March 2020

\section{Reference}

1. Hu Y, Xi Z, Liu X, Wang J, Guo Y, Ren D, Wu H, Wang X, Chen B, Liu Q. Identification and molecular characterization of Wolbachia strains in natural populations of Aedes albopictus in China. Parasites Vectors. 2020;13:28. https://doi.org/10.1186/s13071-020-3899-4.

\section{Publisher's Note}

Springer Nature remains neutral with regard to jurisdictional claims in published maps and institutional affiliations.

Ready to submit your research? Choose BMC and benefit from:

- fast, convenient online submission

- thorough peer review by experienced researchers in your field

- rapid publication on acceptance

- support for research data, including large and complex data types

- gold Open Access which fosters wider collaboration and increased citations

- maximum visibility for your research: over 100M website views per year

At $\mathrm{BMC}$, research is always in progress.

Learn more biomedcentral.com/submissions 